研

究

\title{
アークプラズマにより作製したPd 超微粒子の厚膜化
}

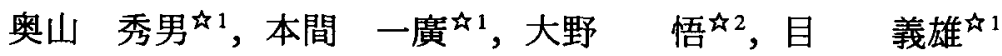 \\ 41物質・材料研究機構, [(旧) 金属材料技術研究所], 干305-0047つくば市千現1-2-1. \\ 中2 石川県つくば科学技術情報センター，矛350-0047つくば市千現 2-1-6つくば研究支援センターA26.
}

\section{Fabrication of Palladium Layers from Ultrafine Particles Synthesized by DC Plasma}

\author{
Hideo Okuyama ${ }^{\star 1}$, Kazuhiro Honnma ${ }^{\text {} 1}$, Satoru Ohno ${ }^{\text {2 }}$, Yoshio Sakka 1 \\ 1 National Institute for Materials Science, [Formerly: National Research Institute for Metals], 1-2-1 Sengen, Tukuba $305-0047$. \\ ${ }^{4}$ Isikawa Sunrise Creation Organization, Tukuba Center Inc A26, 2-1-6 Sengen, Tukuba 305-0047.
}

Received December 22, 2000

\section{SYNOPSIS}

Fabrication of palladium layer having flexible shape and strength was attempted by using ultrafine particles. Continuous process of the preparation of palladium ultrafine particle and their deposition on a filter substrate of stainless steel fiber has been demonstrated. The layer was separated from the filter and/or cracked during the heating due to the following reason; (1) low density of the deposited layer, (2) density distribution along the depth direction of the layer, and (3) stress between the layer and the filter coming from the shrinkage of layer and expansion of filter. To solve the above problem, the layer was compressed and heated under pressure. Uniform and well-contacted layer on the stainless steel filter was successfully prepared.

KEY WORDS

DC plasma, palladium, film, ultrafine particle, filter

\section{1 緒 言}

金属超微粒子は通常のバルク状金属には見られない特異な 性質やバルクの特性をさらに強調した特性，たとえば磁気特 性の変化, 光の選択吸収や化学反応性の增大, 低温㛙結性な どを発現するこが知られており，磁気記録材料，触媒，セン サ一等の実用化へ向けた開発が進められている ${ }^{1,2)}$.このよう な超微粒子の特徵を有する 2 次元あるいは 3 次元形状の均質 な厚膜形成が可能となれば新しい機能性材料の応用の一端と なることが期待される.

超微粒子は，その高表面活性な特徴ゆえ，易凝集・焼結性 を示す ${ }^{1-3)}$. そのため, 従来の粉末成形法による厚膜化，つま り，作製・回収後の集合体(超微粉)を用いて成形体を作製す ることは，既に数珠状あるいは塊状となった凝集体あるいは 焼結体を成形することに等しく，任意の形状を有する均質な 膜を形成することは至難である，そこで，凝集前の個々の超 微粒子を堆積・厚膜化する技術，すなわち超微粒子の作製・成 形一貫プロセスの確立が求められてきた.

これまで,生成直後の超凯粒子を利用した厚膜形成方法とし て,プラスマ溶射法やガスデボジション法が知られているる 前者は,プラズマフレーム中に投入した原料粉の微小な液滴，
あるいはそれが固化した超微粒子またはクラスターを直接基 板上に噴霧する方法であるが，この方法で得られる溶射皮膜 は，ブラスマフレームのサイスの制約やその中の温度分布の 存在から，連続皮膜と粉体の集合体からなる皮膜の共存が生 じる場合があり，膜の均質性に欠ける．また，後者は，プラ スマ法やガス中蒸発法などにより作製した超沜粒子をキャリ アガスにより搬送し，ノスルから噴出させて基板上に堆積膜 を形成する方法であるが，この方法では，微粒子の吹き付け による基板への付着・固定化を必要とするため，ノズル先端 を細く設計しなければならず, 2次元あるいは3次元形状の厚 膜の形成にはノスルの走查を必要とし，大面積の均一膜の形 成には不向きである。

一方，著者らはこれまでに「活性プラズマー金属」反応法 を用いて種々の超微粒子を作製してきた ${ }^{4-6)}$.この方法は，水 素や窒素などのガス雾囲気中において金属をアーク溶融する 際に生じる溶融金属の強制蒸発現象により金属を粒子化する ものである.このとき，雾囲気ガスを連続的に導入し気流を 生じさせることによって，製造された超微粒子をガスの流れ に乗せ連続的に搬出することも可能である．この超微粒子の エアロゾルを任意形状のフィルターを通じ,吸引罳過すれば, 
フィルター上に任意形状に形成された均質な超微粒子の膜を 得ることができると考えられる．形成された膜は，逆圧をか けて剥離することも出来るが，フィルターの材質に金属短織 維を選択しそのまま利用することで超微粒子膜に強度を付与 させることも可能と考えられる.本研究では,「活性ブラズマ 一金属」反応法による金属超微粒子の製造とその膜化の過程 を連続プロセス化することを試みた．なお，超微粒子化する 材料には，水素透過膜として利用され，強度を保持した膜の 作成が期待されているPdを選択した

\section{2 実験方法}

本実験に用いた超微粒子製造装置の概略図を Fig.1に示す. 本装置は大別して, 超微粒子発生室, 超微粒子堆積用フィル ター(Fig.1(b)), 圧力調整用フィルター, アーク放電用直流電 源および真空排気系の各部より構成されている.

超微粒子の作製は, 所定の $\mathrm{H}_{2}-\mathrm{Ar}$ 混合ガス雾囲気中で, 水冷 銅ハース上に載置した金属試料(陽極)と放電用タングステン 電極 (陰極) 間で直流アークを発生させ, 金属試料を溶融する

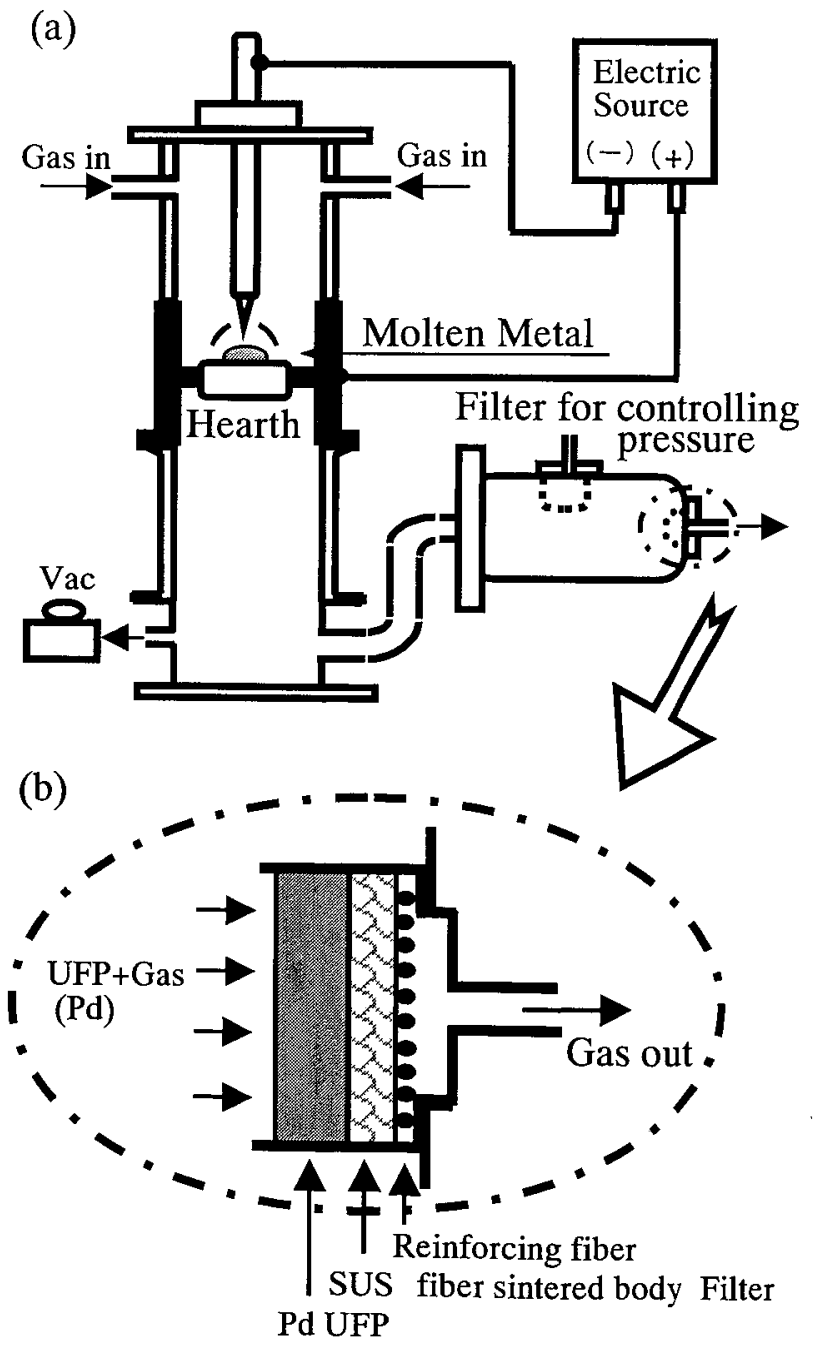

Fig.1 Schematic apparatus of (a) DC-plasma reactor for preparation of ultrafine particles and (b) filter for depositing ultarafine particles.
ことによって行われる，発生した超微粒子は，反応ガスとと もに超微粒子堆積用フィルター(以下フィルターとする)上へ 搬送され堆積される.本実験に使用したPd試料は, 金属Pd塊 (純度 > $99.99 \%$ )を $5 \% \mathrm{H}_{2}-\mathrm{Ar}$ 霝囲気中でボタンアーク溶解する ことにより調製した。なお，試料重量は約 $36 \mathrm{~g}(3 \mathrm{ml})$ とした.

超微粒子作製条件をまとめて Table 1に示す. 得られた超微 粒子の平均粒径は, TEM 観察からおよそ50nmであった。超 微粒子のフィルター上への堆積時間は, 6 30 min 範囲とし た.このフィルターは, 耐熱性および強度を考虑し, 厚さ約 $0.7 \mathrm{~mm}$ ステンレス製フィルター(日本精線(橵製・フィルター NF3M-06S) を用いた(Fig.1 (b)). このフィルターは, ステンレ ス短瀻維焼結体 (線径約 $3 \mu \mathrm{m}$ ) およびこれを補強する層 (ステ ンレス網(線径約 $0.3 \mathrm{~mm})$ ) より構成されている. 得られた超微 粒子堆積膜は, $\mathrm{Ar}$ 気流中に 6 8 時間放置後, 約 $5 \% \mathrm{Air}-\mathrm{Ar}$ 気 流中に 10 時間放置することより安定化処理 (超微粒子表面の 酸化)した》後, 大気中に取り出した.

上記方法によって得られた超微粒子堆積膜(以下堆積膜と する)は，超微粒子間の固定をはかる目的で㜔成を行った。 Table 2 に焼成条件をまとめて示す.なお，焼成前の処理とし て, 無加圧または圧力 $0.5 \sim 4 \mathrm{t} / \mathrm{cm}^{2}$ の範囲での一軸プレス成形 を選択した。前述のように，超微粒子表面には，大気中で取 り扱うための酸化皮膜が存在することから，雾囲気ガスは，

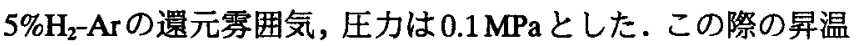
速度は, $2 \sim 10^{\circ} \mathrm{C} / \mathrm{min}$ の範囲とし, 焼成温度は後述する Pd超 微粒子の熱収縮曲線の結果から決定した。得られた堆積膜の

Table 1 Preparation conditions of Pd ultrafine particles.

\begin{tabular}{c|l}
\hline \hline Gas atmosphere & $50 \% \mathrm{H}_{2}-\mathrm{Ar}$ \\
\hline Atmospheric presser & 760 torr \\
\hline Arc current & $150 \mathrm{~A}$ \\
\hline Arc voltage & $30 \sim 40 \mathrm{~V}$ \\
\hline Deposition time & $6 \sim 30 \mathrm{~min}$ \\
\hline
\end{tabular}

Table 2 Sintering conditions of Pd deposited layers.

\begin{tabular}{c|l}
\hline Compaction pressure & $0 \sim 4 \mathrm{t} / \mathrm{cm}^{2}$ \\
\hline Gas atmosphere & $\mathrm{AR}, \mathrm{H}_{2}-\mathrm{Ar}$ \\
\hline Atmospheric pressure & $0 \sim 760$ torr \\
\hline Heating rate & $3 \sim 20^{\circ} \mathrm{C} / \mathrm{min}$ \\
\hline Sintering temperature & $500 \sim 700{ }^{\circ} \mathrm{C}$ \\
\hline
\end{tabular}


表面および断面の形態を SEM(トプコン(侏)製 SM-300)で観察 した.

\section{3 実験結果および考察}

3.1 Pd 超微粒子圧粉体の熱収縮曲線

Pd堆積膜の焼成条件の決定は, 上述の条件で作製したPd超 微粉 (安定化処理を施したPd 超微粒子) を用いて行った. 粉 末を一軸ハンドプレスで成形し,この圧粉体 (相対密度 : 約 $30 \%)$ を還元ガス雾囲気中 $\left(5 \% \mathrm{H}_{2}-\mathrm{Ar}\right.$, 圧力 : $\left.0.1 \mathrm{MPa}\right)$ における 昇温 $\left(5^{\circ} \mathrm{C} / \mathrm{min}\right)$ 時の収縮過程 (熱収縮曲線) をディラトメー ター(ULVAC DL-1500) により調べた. その結果を Fig.2 に示 す. なお, 比較のために, Arガス雾囲気における熱収縮曲線 結果も併せて示す. 同図に見られるように, 還元雾囲気中で 昇温した Pd超微粒子圧粉体は, 温度上昇にともない, 低温領 域で大きく収縮した後, $500^{\circ} \mathrm{C}$ 以上では緩やかに収縮が進行 することが認められた. なお, $180^{\circ} \mathrm{C}$ 付近で急激な収縮の進 行が認められたが, $\mathrm{Ar}$ 雾囲気中での昇温との比較から, 還元 雾囲気による安定化処理皮膜(超微粒子表面の酸化皮膜)の還 元に伴うものと考えられる. また, 高温では粒成長が著しく なるため, 本実験における堆積膜の焼成条件は, 還元雾囲気 中で焼成温度 $500 \sim 700^{\circ} \mathrm{C}$ の範囲とした.

(a)

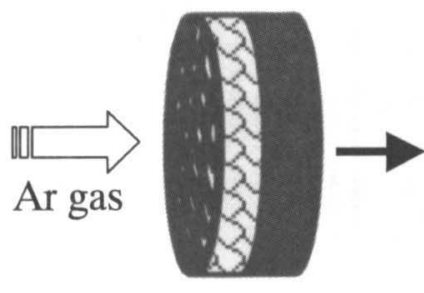

\section{2 堆積膜単体 (Pd 超微粒子のみ)の焼成}

本実験で得られた堆積膜と超微粒子圧粉体では充填状態の 相違により焼結挙動が異なることも予想される.そこで， Fig.3(a)に示すように, 逆圧をかけてフィルター部から分離した

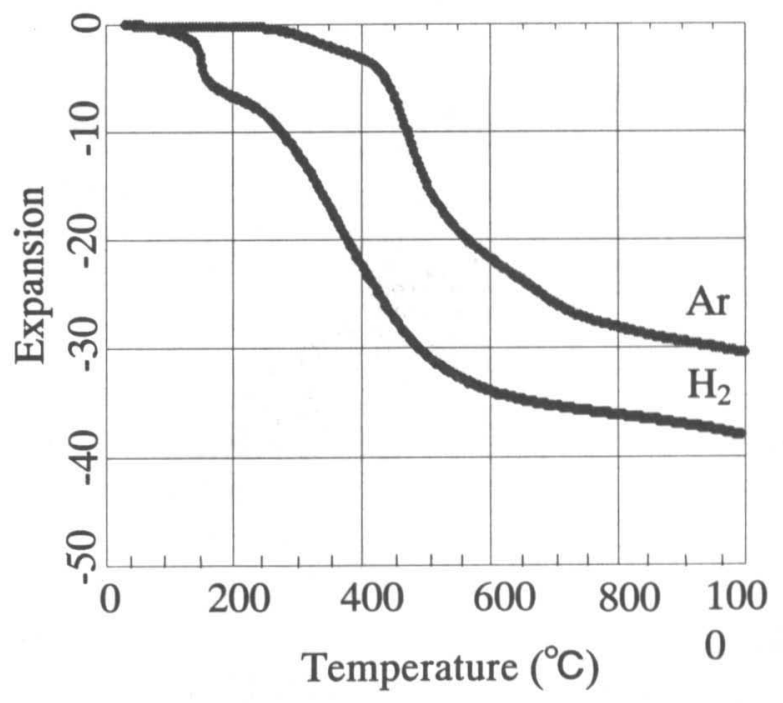

Fig.2 Shrinkage curves of $\mathrm{Pd}$ compacts at a heating rate of $5^{\circ} \mathrm{C} /$ $\mathrm{min}$ in hydrogen and $\mathrm{Ar}$ atmosphere.
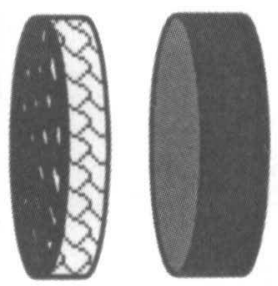

Filter Pd UFP

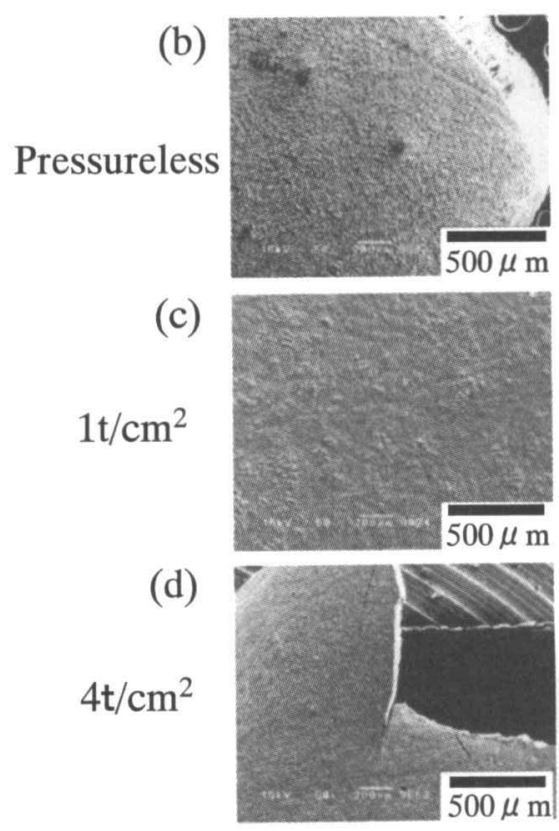

Surface
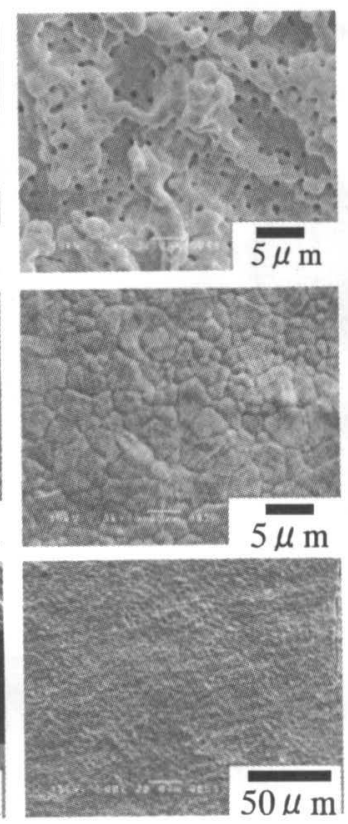

Surface
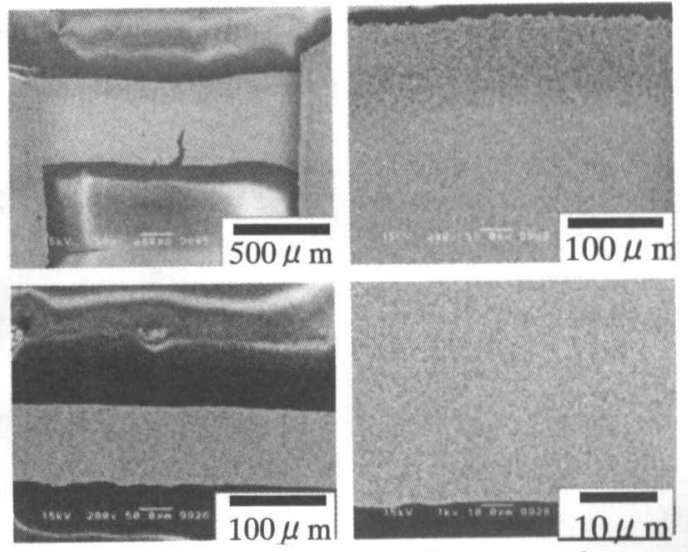

Cross section

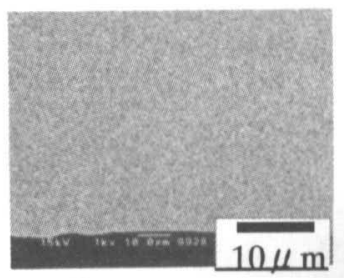

Cross section

Fig.3 (a) Schematic of Pd compact separated from the filter and SEM photographs of the compacts pressed at (b) 0 (c) 1 and (d) $4 \mathrm{t} / \mathrm{cm}^{2}$ after sintering at $600^{\circ} \mathrm{C}$ for $30 \mathrm{~min}$. 
$P d$ 超微粒子膜単体 (膜厚 $\fallingdotseq 1.3 \sim 1.7 \mathrm{~mm}$, 直径 $=10 \mathrm{~mm}$ ) を無加圧 および一軸プレスを用いて成形圧力 $0.5 \sim 4 \mathrm{t} / \mathrm{cm}^{2}$ の範囲で成形し た. 得られた試料成形体は, $5 \% \mathrm{H}_{2}-\mathrm{Ar}$ の雾囲気 (圧力 $0.1 \mathrm{MPa}$ ) において, $5^{\circ} \mathrm{C} / \mathrm{min}$ の速度で $600^{\circ} \mathrm{C}$ まで昇温し $30 \mathrm{~min}$ 保持し た. なお, 無加圧試料の見かけ密度は，その形状から，約 $5 \%$ であった. Fig.3(b-d)に成形圧力を変化させて焼成した試料の 表面と断面のSEM写真を示す. 同図に見られるように，加圧 成形しないで焼成した試料 Fig.3(b) の全体の形状は，フィル ターに接した面を凹としたドーム型のように収縮しており， その表面には多数のピットが見られた。 また，断面の写真か ら膜厚はおよそ $600 \mu \mathrm{m}$ で表面層, (写真上部) と中央部 (写真 中央部)では気孔率に違いがあり, 表面層がより粗になている ことがわかる.この原因は発生した超微粒子がガスによって 搬送されフィルター上に堆積する際, 初期における堆積層と その後の堆積層に密度差が生じたためと考えられる.すなわ ち, 堆積初期には, ステンレスフィルターがフィルター材で あるが, 堆積の進行とともに堆積膜自身がフィルタ一材とし て働く. いわゆる目詰まりによる吸引圧低下によるものと思 われる. $1 \mathrm{t} / \mathrm{cm}^{2}$ で成形した試料 Fig.3(c) は, 平滑な円形(径約 $8.8 \mathrm{~mm})$ を呈しており,割れや剥離も認められず, 厚さ約 $70 \mu \mathrm{m}$ のほぼ均質な焼結体膜が得られた。しかし，さらに成形圧を 高くした $4 \mathrm{t} / \mathrm{cm}^{2}$ の試料(Fig.3(d)) は, 一部に剥離した箇所があ り全体的に割れが生じていた。剥離した原因は定かでないが， 粉体を高圧で成形した際に不均一成形によっておこるラミ ネーション現象に関係するものと考えられる．以上のことか ら本実験における超微粒子堆積膜の焼成には, ある程度の加 圧成形が必要であり，その圧力はおよそ，1 $\mathrm{t} / \mathrm{cm}^{2}$ 前後が適当 であると考えられる。

\section{3 フィルター付堆積膜の焼成}

フィルター付堆積膜の焼成 (雾囲気: $5 \% \mathrm{H}_{2}-\mathrm{Ar}$, 圧力: $0.1 \mathrm{MPa}$, 昇温速度: $5^{\circ} \mathrm{C} / \mathrm{min}, 600^{\circ} \mathrm{C}$ で $30 \mathrm{~min}$ 保持した後炬冷) を行った 試料表面のマクロ写真を Fig.4 に示す. 焼成前処理の成形は, 3.2節の堆積膜単体の場合と同じである.これに見られるよう に，無負荷の場合，Pd超微粒子堆積膜はフィルター部から剥 離して中央部に丸まった形で焼結した。この主因は, 上述し たPd超微粒子堆積膜単体の試料と同様に, 膜の堆積方向の密 度に差異が生じたことにより不均一な収縮が進行したことに よるものと思われる. 成形圧 $500 \mathrm{~kg} / \mathrm{cm}^{2}$ の試料はフィルター に一部付着しているものの割れや剥離が認められた. 成形圧 $1 \mathrm{t} / \mathrm{cm}^{2}$ の試料は, フィルターへの密着性は良いが格子模様の 割れが膜全体に見られた. 2 およ゙ $4 \mathrm{t} / \mathrm{cm}^{2}$ で成形した試料はそ の傾向がさらに強調された形で膜全体に微細な割れが多数認 められた.

ここで，これまでの実験結果を整理してみると次のように なる.

(1) 堆積膜の見掛け密度が極めて小さく,膜厚方向に対して見 掛け密度が密から粗に変化している。

(2) 焼成時において, 堆積膜は焼結・収縮するが,フィルター は熱膨張するため, 応力がかかる.

以上のようなことが要因となって, 剥離あるいは割れ等が 生じたものと推察される. そこで, これらの要因を取り除く 手法として，(1)は，焼成前処理として加圧すること，また， (2)は, 適度な加圧焼結が有効と考えられる.この方法を利用 することで, 堆積膜の見掛け密度の向上と堆積膜の加圧狫結 による膜ーフィルター間の密着性の改善が期待できる.

\section{4 堆積膜の加圧焼結}

Fig.5 (a)に加圧しながら焼成した試料の模式図を示す.図中 に示すように, アルミナ基板上に堆積膜を載せ，その上にア ルミナ基板 (約 $7 \mathrm{~g}$ ), さらにその上に約 $200 \mathrm{~g}$ の重りを載置さ せた. また, 比較のため重りを載せない試料 Fig.5(b)の焼成も 行った (アルミナ基板 $7 \mathrm{~g} / \mathrm{cm}^{2}$ は載置). 焼成は, 3.3 節フィル タ一付堆積膜の焼成の場合と同じ条件で行った。得られた堆 積膜の表面と断面の写真をFig.6に示す.これに見られるよう に約 $200 \mathrm{~g} / \mathrm{cm}^{2}$ の重りを載置させた試料は, 平滑な円形 (径約 $10.0 \mathrm{~mm})$ を呈しており, 表面の割れや剥離も認められず結晶 粒径約 $1 \sim 3 \mu \mathrm{m}$ の平滑な面を持ち, 断面の写真からフィルター
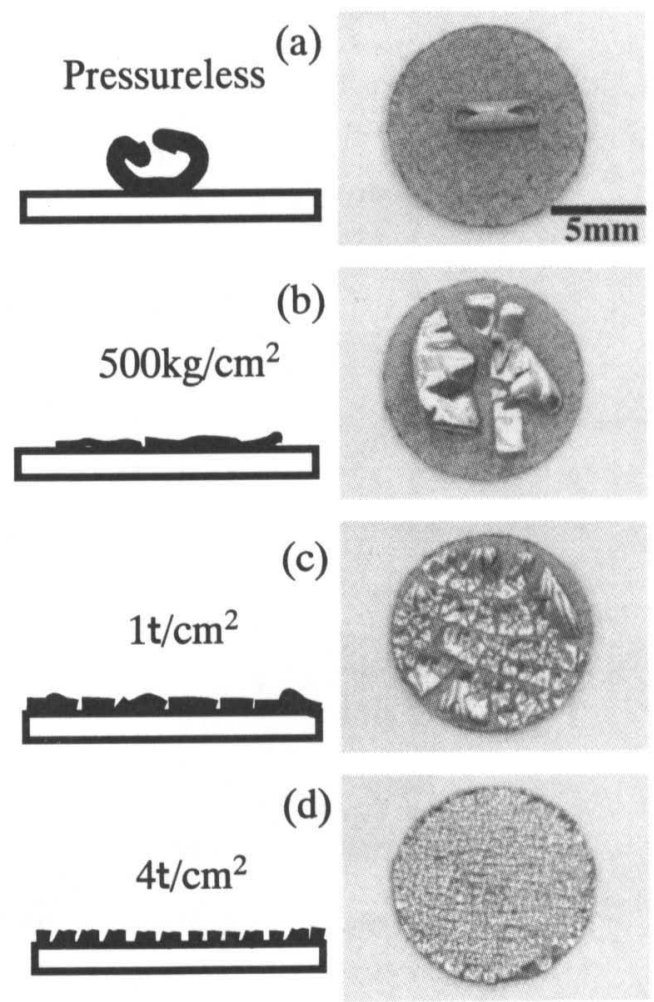

Fig.4 Schematic and macroscopic views of layers after normal sintering without pressure.

(a)

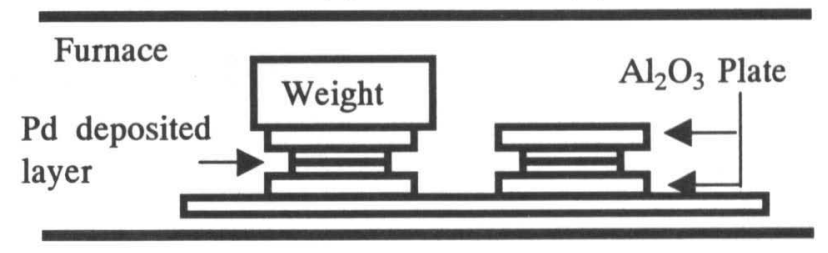

Fig.5 Schematic of pressure sintering (a) with weight and (b) without weight. 

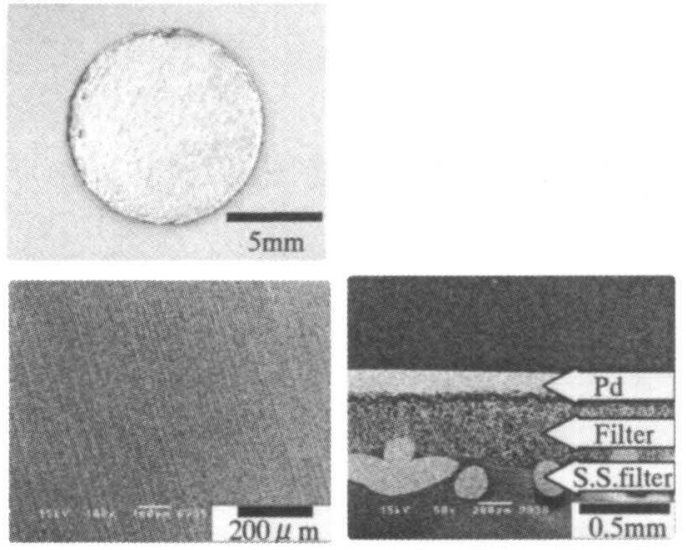

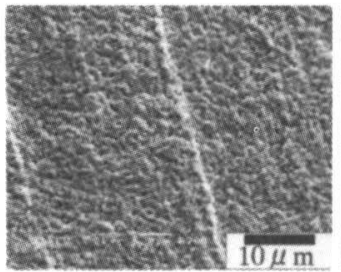

Surface

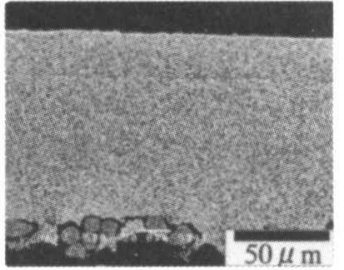

Cross section
Fig.6 SEM photographs of the deposited layer after pressure sintering.

上に厚さ約 $80 \mu \mathrm{m}$ のほぼ均質な Pd焼結体厚膜が生成している ことが認められた.つまり, この堆積膜は, 熱処理前の加圧 成形を行ったことによる密度差の改善および, 焼成時の加圧 焼結による瀻維フィルターへの堆積膜の適度な食い込みによ る密着性の改善が達成されている. 一方, 重りを載せないで 焼成した試料Fig.5(b)は,フィルターに一部付着しているもの 多数の剥離や割れが認められFig.4(b)と同様な様相を示した.

\section{4 ま と め}

超微粒子応用の一環として, 強度を持ち, 形状に任意性の ある比較的均一なPd超微粒子厚膜作製の可能性について検討
し，次の結果を得た.

(1)「活性プラズマー金属」反応法を用いて合成したPd超微粒 子をそのまま,任意形状の金属短絨維フィルター上に均質 に堆積させることが可能となった.

(2) 堆積膜は, 膜の堆積方向の密度差が生ずるため, 焼成の前 に適度な成形を施す必要がある.

(3) 堆積膜の焼成には,膜の剥離阻止や割れの抑制のため加圧 焼結が有効である。

\section{謝辞}

本論文の作成において, 有益なコメントを頂いた金属材料 技術研究所プロセス制御研究部 打越哲郎主任研究官,鈴木 達 主任研究官に感謝いたします

\section{文献}

1) 斉藤進六監修: 超微粒子ハンドブック,フジ・テクノシス テム, (1990).

2) 林主税, 上田良二, 田崎明編: 超微粒子, 創造科学技術, 三 田出版, (1988).

3) Y.Sakka and T.Uchikoshi: "Surface chemistry and sintering characteristics of nickel ultrafine powders", Powder Metall., 36 (1993)179-185.

4) 大野悟,宇田雅廣:"「水素プラズマー金属」反応法における 各種金属超微粒子発生の速度について", 日本金属学会誌, 48(1984)640-646.

5) 宇田雅廣, 大野悟: "溶融金属一窒素プラズマ応法による超 微粒子の作製", 日本化学会誌, 1984(1984)862-868.

6) Y.Sakka, H.Okuyama, T.Uchikoshi and S.Ohno: "Characterization of degraded surfaces of $\mathrm{Al}$ and AlN ultrafine powders", Nanostruct. Mater., 5(1995)577-588.

7) 大野悟, 宇田雅廣: "低酸素分圧下におけるニッケルおよび クロム超微粒子の室温酸化 ", 日本金属学会誌, 53(1989) 1062-1067. 